\title{
Influence of Livestock Grazing Strategies on Riparian Response to Wildfire in Northern Nevada
}

\author{
K. N. Dalldorf, ${ }^{1}$ S. R. Swanson, ${ }^{2}$ D. F. Kozlowski, ${ }^{1}$ K. M. Schmidt, ${ }^{1}$ R. S. Shane, ${ }^{1}$ and G. Fernandez ${ }^{3}$ \\ Authors are ${ }^{1}$ former graduate student and ${ }^{2}$ Associate Professor, Department of Natural Resources and Environmental Science, University of Nevada, \\ Reno, Reno, NV 89512, USA; and ${ }^{3}$ former Director, Center for Research Design and Analysis, and Professor, Department of Resource Economics, \\ University of Nevada, Reno, Reno, NV 89512, USA.
}

\begin{abstract}
In 1999-2001 wildfires burned 1.13 million ha across northern Nevada, burning through many grazed riparian areas. With increases in wildfire frequency and extent predicted throughout the Great Basin, an understanding of the interactive effects of wildfire, livestock grazing, and natural hydrologic characteristics is critical. A comparison of pre- and postfire stream surveys provided a unique opportunity to statistically assess changes in stream survey attributes at 43 burned and 38 unburned streams. Livestock grazing variables derived from an extensive federal grazing allotment inventory were used to identify interactive effects of grazing strategies, fire, and natural stressors across 81 independent riparian areas. Differences between baseline and "postfire" stream survey attributes were evaluated for significance using the nonparametric Mann-Whitney test for paired data. Binary logistic regression models evaluated the influence of fire, grazing, and hydrologic characteristics on observed stream survey attribute changes. Grazing attributes contributed most significantly to the bankfull width increase and bank stability rating decrease models. The odds of bankfull width degradation (increase in bankfull width) decreased where there had been rest is some recent years compared to continuous grazing. As the number of days grazed during the growing season increased, the odds of bank stability degradation also increased. The occurrence of fire was not significant in any model. Variation in the riparian width model was attributed primarily to hydrologic characteristics, not grazing. For the models in which grazing variables played a role, stream survey attributes were more likely to improve over time when coupled with a history of rotational grazing and limited duration of use during the growing season. This supports long-term riparian functional recovery through application of riparian complementary grazing strategies.
\end{abstract}

Key Words: grazing history, Great Basin, logistic regression, stream survey

\section{INTRODUCTION}

Riparian areas throughout the Great Basin comprise a small percentage of total watershed area, yet provide vital resources to the region's wildlife, domestic livestock, and human populations. In 1999-2001 a series of catastrophic wildfires burned to or through many northern Nevada riparian areas critical to livestock production, a dominant public land use. Other historic and present-day land uses occurring in northern Nevada riparian areas include mining and recreation.

The 1999 wildfire season, the most widespread fire season in the state's recorded history, burned more than 445000 ha (BLM 2006). Approximately 647000 additional ha burned in 2000 and 2001 (BLM 2006). Between 2001 and 2008, approximately 486000 additional ha burned. Increased fire frequency and extent in recent decades has been attributed to

Research was funded in part by the US Forest Service National Fire Plan and through Nevada Agricultural Experiment Station and University of Nevada Cooperative Extension project 1320-153-52MB.

Mention of a proprietary product does not constitute a guarantee or warranty of the product by USDA or the authors and does not imply its approval to the exclusion of the other products that also may be suitable.

Correspondence: Sherman Swanson, Dept of Natural Resources and Environmental Science, University of Nevada, Reno, 1000 Valley Road, Reno, NV 89512, USA. Email: sswanson@cabnr.unr.edu

Manuscript received 4 April 2011; manuscript accepted 30 June 2012.

(c) 2013 The Society for Range Management fire suppression policies, spread of invasive annuals, increased development of a wildland-urban interface, climate change (Miller and Tausch 2001; Brunson and Shindler 2004; Chambers et al. 2008), and decreased grazing use (Launchbaugh et al. 2008). With increases in wildfire frequency and extent predicted throughout the Great Basin (McKenzie et al. 2004) and the importance of riparian areas to many watershed functions and resource values (Prichard et al. 1998), an understanding of the effects of wildfire in grazed riparian systems is critical.

The broad occurrence of the 1999-2001 wildfires, coupled with an extensive inventory of prefire stream survey data housed by federal and state agencies, provided a unique opportunity to study fire effects on 81 independent riparian study sites across northern Nevada. Schmidt (2008) investigated the effectiveness of watershed characteristics and hydrologic regime as predictors of stream survey attribute changes on burned and unburned streams. While some variance could be explained by the watershed and hydrologic factors, unexplained variance suggested additional forces were influencing stream attributes over time.

Livestock grazing, a prevalent land use with potentially significant impacts on riparian areas, had not been accounted for in Schmidt's (2008) study. The proper management of livestock for riparian resources has been the focus of land managers in recent decades. Strategies for adaptive management (Swanson et al. 2006; Wyman et al. 2006; Burton et al. 2011) suggest riparian livestock grazing, applied with appro- 
priate site-specific timing, duration, and rotation of use, can be effective for maintaining or restoring riparian functionality while allowing for sustainable harvest of livestock forage. Yet much of what has been learned about riparian grazing management stems from the accumulation of experience from individual case studies or research with few replications. Svejcar and Havstad (2009) suggest that the traditional scale of grazing research must expand to address landscape issues such as livestock distribution or the effect of rotation and other strategies on foci such as riparian areas. They point out that the review by Briske et al. (2008) questioning the efficacy of rotation strategies had to rely almost entirely on small paddock studies and limited common objectives. Furthermore, the interactive effect of specific riparian livestock grazing strategies and wildfire remains unexplored.

Recent fire and livestock grazing interaction studies have targeted primarily uplands where the effectiveness of grazing for vegetation or fuels management has been explored (Davison and Smith 1997; McAdoo et al. 2007; Diamond 2009; Schmelzer 2009). In riparian areas, shifts in plant species composition and structure and distribution of fuel loads, as well as changes in microclimate and areal extent of riparian areas, have been influenced by livestock grazing and other land uses (Dwire and Kauffman 2003). Livestock grazing has the potential to alter riparian areas and presumably fire effects in riparian areas, most directly through the utilization of herbaceous and woody vegetation (Clary and Webster 1989) and through direct geomorphic impacts (i.e., bank alteration resulting in decreased stability; Trimble and Mendel 1995). Livestock management may positively or negatively influence riparian functional condition and the ability for the channel to withstand extra stress resulting from wildfire (Prichard et al. 1998; Wyman et al. 2006). Yet little is known about the response of riparian vegetation and geomorphic attributes to wildfire when coupled with the effects of specific grazing strategies.

Access to public agency stream survey and various grazing record data provided an opportunity to explore the livestock grazing/wildfire effects on an array of riparian measures. Derivation of grazing histories pertaining to the timing, duration, and rotation of use over a 20 -yr period occurring in 81 independent riparian areas provided an opportunity to account for previously unexplained model variance. The exploratory objectives of the study were to statistically assess the differences between baseline and resurveyed stream survey attributes and to identify and separate the effects of grazing strategies from the effects of natural stressors on replicate northern Nevada streams. Understanding riparian response to wildfire in relation to watershed characteristics, hydrologic regime, and livestock grazing will provide new tools for rangeland riparian management in anticipation of future wildfire.

\section{METHODS}

\section{Study Area and Site Selection}

Most of Nevada is within the Great Basin physiographic province. The hydrographic structure, topography, and vegetation of the study area reflect that of the Northern and Central

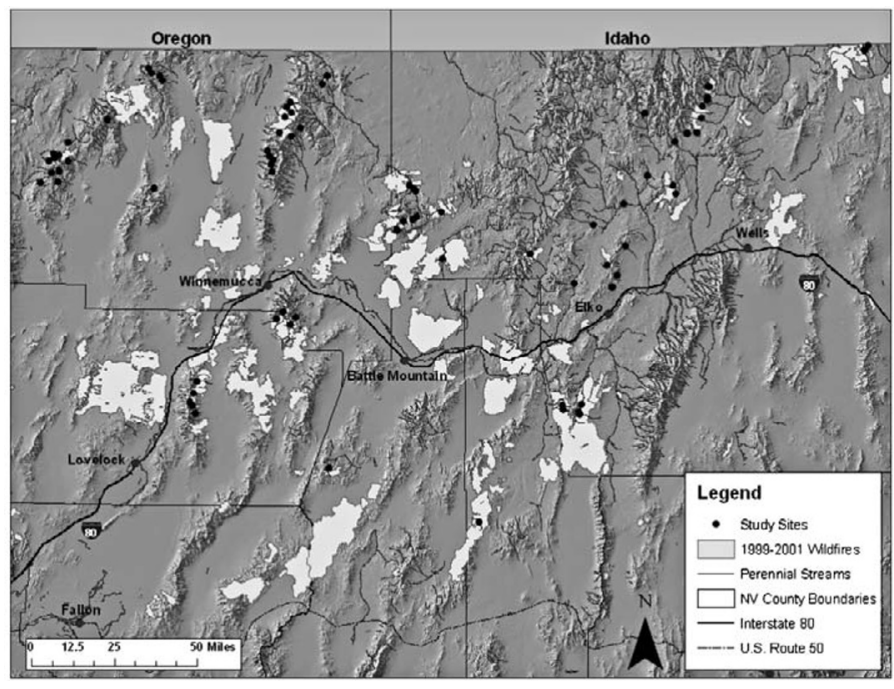

Figure 1. General study area displaying burned and unburned study sites and the extent of the 1999-2001 wildfires. Inset shows area of detail.

Basin and Range Ecoregions III (Omernick 1987; scale 1:7500 000). Most watersheds are internally draining with highly responsive hydrographs. Various Rosgen (1996) stream types depict topographic features of the north- and southtrending fault block valleys and mountain ranges. Variable and limited precipitation along elevational gradients produces diverse, highly adapted, and specialized vegetation throughout the lowlands and uplands of the ecoregions.

Riparian corridors are dominated by common phreatophytic species, including tree species of willow (Salix spp.), gray alder (Alnus incana [L.] Moench), water birch (Betula occidentalis Hook), Fremont cottonwood (Populus fremontii S. Wats), and quaking aspen (Populus tremuloides Michx); shrub species of willow (Salix spp.), Woods' rose (Rosa woodsii Lindl), and redosier dogwood (Cornus sericea L.); and herbaceous species of sedges (Carex spp.), rushes (Juncus spp.), various grasses, and forbs (Manning and Padgett 1995). Uplands species adjacent to the riparian zones are made up primarily of sagebrush species (Artemisia spp.), rabbitbrush (Chrysothamnus spp.), antelope bitterbrush (Purshia tridentata [Pursh] DC.), and various grasses and forbs adapted to the limited precipitation, primarily winter snow. Spring runoff from March-June produces annual peak flows contributing to the spring-fed perennial streams of focus for this study.

In collaboration with the Humboldt Toiyabe National Forest, the University of Nevada, Reno, project team conducted a resurvey in 2005 of streams burned in 1999-2001 and in 2006 of unburned streams. Forty-three burned sites (Fig. 1) along perennial streams were randomly selected based on the following criteria: Sites had experienced wildfire during the 1999-2001 fire seasons, were contained within the Northern and Central Nevada Basin and Range Ecoregions III, and had available prefire stream survey level 3 data with photopoints. For comparison 38 sites along unburned (for $>25$ years) perennial streams (Fig. 1) were randomly selected for resurvey given they had undergone a federal or state stream survey prior to 1999 and shared similar geology, elevation, and slope with burned sites (Schmidt 2008). Each site was independent (i.e., one site per stream, with the exception of three streams 
containing one burned and one upstream unburned site each) and located on US Forest Service (funding agency) land when possible.

Study sites were located on four Bureau of Land Management (BLM) Resource Areas, three US Forest Service Districts, and private land, with the majority of sites managed by the BLM. The 81 selected study sites were contained within 40 federally designated grazing allotments. Grazing data were collected for the pasture/use area containing the stream survey reach of interest.

\section{Grazing Variable Collection}

Grazing data were collected from BLM and US Forest Service allotment and permittee case files. The unit/pasture containing the stream survey reach was first determined using allotment maps. Data regarding the timing, duration, and rotation of use from 1986 to 2005 pertaining to the unit/pasture of interest were pulled from actual use records, allotment management plans, permits, billings, allotment maps, monitoring records, and multiple use decisions with all sensitive information remaining anonymous. The 20 -yr duration for grazing data collection provided an opportunity to capture the effects of long-term grazing use on the riparian study sites. When available, data were pulled first from permittee-provided actual use records, and gaps were filled with assistance from the respective Rangeland Management Specialists and/or other records of use. Average values were calculated for timing and duration variables along with standard deviation to get a sense of variability related to rotational use (Table 1). Given its proximity to mean study site elevation, growing season variables were calculated based on the Tuscarora, Nevada, weather station (National Climatic Data Center 2003). The average last spring freeze occurred on 26 May and the first fall freeze on 30 September for a total growing season of $128 \mathrm{~d}$ at an elevation of $1886 \mathrm{~m}$.

In addition to the grazing variables described above, two sets of grazing strategy variables served as predictors of stream survey attribute change in binary logistic regression analysis. Detailed methods are described in Schmidt (2009). The first set of grazing strategy variables were derived by visually sorting dates of use tables (dates of use plotted by year from 1986 to 2005 for each study site pasture/use area). Patterns were identified and further sorted into similar groupings (STRAT1 and STRAT2) (Table 1). The second set of grazing strategy variables were derived directly from a disjoint cluster analysis (DCA) of grazing variables in which five statistically unique categories were differentiated (STRAT3) (Table 1). All grazing data can be found in Tables S1-S2 (available online at http://dx. doi.org/10.2111/REM-D-11-00065.s1).

\section{Watershed Characteristics and Hydrologic Data}

Physical predictor variables of site slope and watershed characteristics including size, elevation, and slope were determined using ArcMap (ESRI 2009) and National Elevation Dataset $(30 \mathrm{~m})$ coverages available from the USGS (2006). Watershed size and perimeter were used to calculate the circularity ratio or shape of the watershed $\left(\mathrm{R}_{\mathrm{c}}\right)$ (Miller 1953).

Site-specific and peak event precipitation data were unavailable for the study sites. Predictor variables of survey year and
Table 1. Grazing, fire, watershed, and hydrologic variables used as predictors in binary logistic regression models.

\begin{tabular}{|c|c|}
\hline \multicolumn{2}{|r|}{ Grazing predictor variables } \\
\hline \multirow[t]{3}{*}{ Strategy 1 (STRAT 1) } & 1: Rest within recent years \\
\hline & 2: Rotational grazing \\
\hline & 3: Continuous use \\
\hline \multirow[t]{10}{*}{ Strategy 2 (STRAT 2) } & 1: No grazing since 1990 \\
\hline & 2: No grazing since 2001 \\
\hline & 3: Rotation (change of season)—short \\
\hline & 4: Rotation (on vs. off)—short \\
\hline & 5: Rotation (change of season)-long \\
\hline & 6: Rotation (on vs. off)—long \\
\hline & 7: Continuous use, short-late \\
\hline & 8: Continuous use, short-early \\
\hline & 9: Continuous use, short-mid \\
\hline & 10: Continuous use, long \\
\hline \multirow[t]{5}{*}{ Strategy 3 (STRAT 3) } & 1: Sites rested over duration of study \\
\hline & $\begin{array}{l}\text { 2: Rotation of use and rotation of season, } \\
\text { greatest variation of use }\end{array}$ \\
\hline & $\begin{array}{l}\text { 3: One month of early use (Feb.) - midlevel of } \\
\text { variation }\end{array}$ \\
\hline & 4: Rotation of season-relatively high variance \\
\hline & $\begin{array}{l}\text { 5: Four months of grazing (May-Sept.) - low } \\
\text { variance }\end{array}$ \\
\hline AVG DR & $\begin{array}{l}\text { Average number of days rested over 20-yr study } \\
\text { period (1986-2005) }\end{array}$ \\
\hline AVG DR5 & $\begin{array}{l}\text { Average number of days rested in last } 5 \text { yr of } \\
\text { study (2001-2005) }\end{array}$ \\
\hline AVG DR10 & $\begin{array}{l}\text { Average number of days rested in last } 10 \mathrm{yr} \text { of } \\
\text { study (1996-2005) }\end{array}$ \\
\hline AVG DR 15 & $\begin{array}{l}\text { Average number of days rested in last } 15 \text { yr of } \\
\text { study (1991-2005) }\end{array}$ \\
\hline STD DR & $\begin{array}{l}\text { Standard deviation of the number of days rested } \\
\text { over } 20 \text {-yr study period }\end{array}$ \\
\hline STD ON & Standard deviation of the grazing start date \\
\hline STD OFF & Standard deviation of the grazing end date \\
\hline STD MGPD & Standard deviation of the midgrazing period date \\
\hline Y REST & Number of years rested over study period \\
\hline AVG GSDG & Average number of growing season days grazed \\
\hline AVG DGBLSF & $\begin{array}{l}\text { Average number of days grazed before last spring } \\
\text { freeze }\end{array}$ \\
\hline AVG DGAFFF & Average number of days grazed after first fall frost \\
\hline AVG ON & Average grazing start date \\
\hline AVG OFF & Average grazing end date \\
\hline AVG MGPD & Average midgrazing period date \\
\hline
\end{tabular}

Fire, watershed, and hydrologic predictor variables

Burned/unburned Categorical variable

Site slope (\%) Slope of the riparian study sites

Watershed size (ha) Watershed size calculated above riparian study site

Circularity ratio $\quad \mathrm{R}_{\mathrm{c}}$ calculated from watershed size and perimeter length (Miller 1953)

Watershed elevation $(\mathrm{m}) \quad$ Average watershed elevation above each site

Watershed slope (\%) Average watershed slope above each site

Precipitation mean $(\mathrm{cm}) \quad$ Precipitation average from 1970 to 2000

Survey year precipitation Resurvey year precipitation

(cm)

Watershed volume $\left(\mathrm{m}^{3}\right) \quad$ Watershed area $\times$ mean watershed precipitation 
mean precipitation were therefore calculated as the weighted average of all pixels within each watershed boundary using precipitation records from the PRISM Group (2006). The spatial resolution was $2.5 \operatorname{arcmin}(4 \mathrm{~km})$. PRISM data were converted into water years (1 October-30 September) from which monthly averages were used to calculate the yearly average for the specific survey year and the mean precipitation for the years 1970-2000. Volumes of water within the watershed were calculated from watershed size and precipitation data (Schmidt 2008). Watershed and hydrologic variables can be found in Table S3 (available online at http://dx.doi.org/ 10.2111/REM-D-11-00065.s1). Table 1 lists all potential grazing and physical predictors.

\section{Stream Survey Data}

Baseline stream surveys were conducted by the Nevada Department of Wildlife, Forest Service, or BLM using the General Aquatic Wildlife System (GAWS; USFS 1985) or Modified GAWS (BLM 2002) 5 to 19 (the majority were 5-11) years prior to resurvey. Copies of the most recent, pre-1999, baseline surveys and associated photographs were collected from the respective agency offices.

After training with the Nevada Department of Wildlife stream survey crew, the project team employed the Modified GAWS methods to conduct the resurvey of burned sites in summer of 2005 and unburned sites in summer of 2006 using the same number and spacing of transects (Kozlowski 2007; Kozlowski et al. 2010; Schmidt 2008). Photographs and GPS were used to verify the location of baseline survey points. Established stations comprised four or five transects spaced at 15.2 or $30.5 \mathrm{~m}$ apart. Eight of 10 stream survey attributes were measured at each transect with the remainder (dominant riparian vegetation and woody organic debris ratings) assessed as one singular value representative of the entire station reach. The mean for continuous variables or median for ordinal variables were calculated for attributes measured at each transect. The difference between baseline and resurvey means and medians, and singular values for vegetation and debris ratings, were used as response variables in statistical analyses.

The five stream survey attributes selected as response variables for this study were those with the most complete baseline and resurvey datasets available. Variables included 1) bankfull width, 2) total riparian width (width of riparian vegetation maintained by water from active stream channel, not including the active channel itself), 3) bank cover, 4) bank stability, and 5) dominant bottom material fining (becoming less coarse). Ungulate damage was not assessed given differences in survey methods, which made baseline ratings difficult to compare. Baseline and resurvey stream survey data can be found in Tables S4-S5 (available online at http://dx.doi.org/10. 2111/REM-D-11-00065.s1).

\section{Analysis Procedures}

For this observational longitudinal study, fire, grazing, geomorphic, and hydrologic variables were employed as predictors of change or response of stream survey attributes. As binary logistic regression (BLR) techniques did not assume the relationships between predictors and the binary response to be linear (the relationship between the log odds of the response and predictors is considered to be linear) or residuals to require normal distribution or homoscedasticity as in the case of MLR (Fernandez 2003), BLR was utilized as the primary statistical assessment tool.

Differences between pre- and poststream survey attributes were evaluated for significance using the nonparametric MannWhitney medians test for paired data. Calculated differences were translated into binary responses with the value one representing an event (negative change or degradation) and the value zero representing the nonevent (positive change/improvement or no change) to maintain consistency with previous related studies (Kozlowski 2007; Schmidt 2008). Predictor variables were divided by meaningful units as determined from scatterplots to assist in the interpretation of binary logistic regression odds ratio estimates for which the odds of the event are related to a one unit change in predictor variable.

The SAS macro LOGISTIC (Fernandez 2003) was used to run the stepwise model selection process to identify the best-fit model comprising significant predictors $(P \leq 0.15)$ driving each response variable event. A $P$ value of 0.15 allowed the detection of environmental change that might otherwise have been undetectable with a $P$ value of 0.05 due to spatial variability and relatively small number of replications (Peterman 1990). Variables were required to maintain odds ratio estimate $95 \%$ confidence intervals that did not contain a value of one. A confidence interval range including a value of one suggests the chance of statistical independence, or neutrality, in which the odds of a degradation event were no more or less likely to occur given a one unit change in the predictor. The final model was required to minimize the Akaike's information criterion score (AIC) and to produce a well-fit model, a high Hosmer and Lemeshow goodness-of-fit $P>0.05$ (Hosmer and Lemeshow 2000). AIC is a model variance statistic adjusted for sample size and number of parameters. If the Hosmer and Lemeshow goodness-of-fit statistic was $>0.05$, we failed to reject the null hypothesis that there were no differences between the observed and expected predictor-response relationships. The relative contribution of each variable was assessed from an estimate derived from a one standard deviation increase in the model predictor and therefore not influenced by the scale of predictor units.

Though effective classification and predictive capacity were not primary objectives of the analyses, Maximum Rescaled $R^{2}$ values based on maximum likelihood estimates, C statistics, Brier scores, and predictive accuracy percentages were evaluated to provide a sense of model accuracy. The $R^{2}$ value was used as a model-fit statistic. $R^{2}$ values could be compared only to other models in this study given the observational nature of the study and inherent unexplained variance. The $\mathrm{C}$ statistic served as an indicator of classification power revealing the percentage of correctly classified observations. Predictive accuracy of the models were evaluated from the Brier scores (the smaller the score the better the predictive capacity) and predictive accuracy percentages at a cutpoint of 0.50. A cutpoint of 0.50 served as a default value at which each observation was classified an event if the estimated probability was $\geq 0.50$ or as a nonevent if $<0.50$. An independent validation data set was not available; therefore, model validity could not be truly assessed. 
Table 2. Baseline and resurvey median values, differences, and MannWhitney test significance results for stream survey attributes. Positive improvements $(+)$ and negative degradation $(-)$ indicated.

\begin{tabular}{lccccc}
\hline & $\begin{array}{c}\text { Baseline } \\
\text { survey } \\
\text { Survey attribute }\end{array}$ & $\begin{array}{c}\text { Resurvey } \\
\text { median }\end{array}$ & median & Difference & $\begin{array}{c}\text { Mann-Whitney } \\
\text { test } P \text { value } \\
(\leq 0.05)\end{array}$ \\
\hline Bankfull width $(\mathrm{m})$ & 3.2 & 2.52 & $-0.68(+)$ & $0.0157^{1}$ \\
Dominant bottom material rating & 3 & 3 & 0 & 0.1276 \\
Riparian width $(\mathrm{m})$ & 9 & 14.38 & $5.38(+)$ & $0.0007^{1}$ \\
Bank cover rating & 1.15 & 1.2 & $0.05(+)$ & 0.2849 \\
Bank stability rating & 1.35 & 1.75 & $0.40(+)$ & $<0.0001^{1}$ \\
\hline
\end{tabular}

${ }^{1}$ Statistically significant based on $P \leq 0.05$.

Logits comprising the BLR equations were used to estimate the $\log$ odds of a degradation event occurrence (response $=1$ ). Model logits were converted into odds ratios for each significant model predictor using the exponential function. Once transformed into odds ratios, the logit could be interpreted as a percent increase in odds given a one unit change in the significant predictor variable and given all other variables remained constant. Odds ratios and $95 \%$ confidence intervals were graphed to provide a visual assessment of odds ratios.

The log odds models, correlating significant predictors to each response variable, were transformed to produce a probability equation from which the probability of the event could be calculated. From the probability equations, plots were produced for each significant contributing predictor to aid in visual interpretation of study-specific predictor-response relationships and to identify event thresholds and potential outliers driving relationships. The range of data set observations was entered into the equation for each predictor independently while all other predictors remained at a constant variablespecific mean. The independent variables were then converted back into the original data form for plot interpretation.

\section{RESULTS}

\section{Stream Survey Attribute Differences}

Significant median differences between baseline and resurvey attributes, detected using the Mann-Whitney test $(P \leq 0.05)$ for paired data (Table 2), occurred for bankfull width, total riparian width, and bank stability rating. All were considered positive. Significant differences were not detected for dominant bottom material and bank cover ratings.

\section{Binary Logistic Regression Models}

Bankfull Width Increase Model. Seventy-two of 81 observations were available to model bankfull width increase. Twenty-one observations were classified as events in which values increased (suggesting degradation). Fifty-two observations were classified as nonevents in which observations either decreased (suggesting improvement) or experienced no change. Three attributes contributed significantly to the final model for which the odds ratio estimates, $95 \%$ confidence intervals, and corresponding data table are displayed in Figure 2. An $R^{2}$ of $0.28, P$ value for

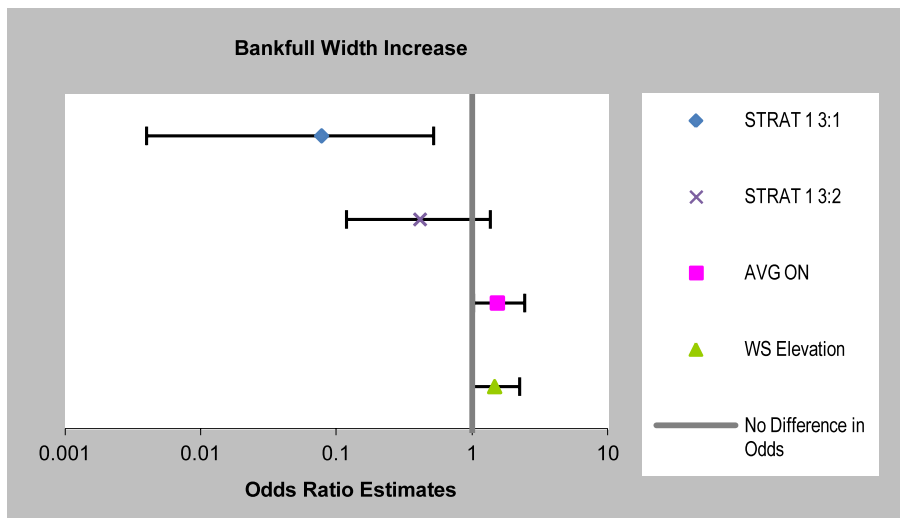

Figure 2. Odds ratio estimates and $95 \%$ confidence intervals for the bankfull width increase model. STRAT 1 3vs1: Grazing strategy one comparison of level 3 (continuous use) to level 1 (rest within recent years), STRAT 1 3vs2: Grazing strategy one comparison of level 3 (continuous use) to level 2 (rotational grazing), AVG ON: average annual grazing start date; WS Elevation: elevation of study site watershed.

the Hosmer and Lemeshow goodness-of-fit statistic of 0.13 , model C statistic of 0.78 , and Brier score of 0.17 suggested the model to be well fitted. The model correctly predicted events and nonevents $70.8 \%$ of the time at a cutpoint probability of 0.50 .

Odds ratio estimates suggest, as grazing strategy (STRAT 1) shifted from level 3 (continuous grazing) to level 1 (rest within recent years), the odds of a bankfull width increase or degradation event decreased by 0.078 times with the two other significant model contributors of average grazing start date and watershed elevation held at an average constant. Similarly, with a shift in grazing strategy from level 3 (continuous use) to level 2 (rotational grazing), the odds of bankfull degradation were 0.415 times less likely with the other two contributors held at a mean constant value. Odds ratio estimate confidence intervals suggest $95 \%$ certainty the odds of a degradation event would fall within a factor range 0.004-0.52 for a shift from level 3 to level 1 , and a range $0.12-1.37$ with a shift from level 3 to level 2 . The confidence interval associated with the shift from level 3 to level 2 contains the value one, suggesting this shift to be less significant $(P=0.15)$ than the shift from level 3 to level 1 $(P=0.03)$ in influencing bankfull width degradation odds.

An odds ratio estimate greater than one was related to a decrease in event odds. For example, as the average annual grazing start date (AVG ON) increased by one unit (30 Julian d), the odds of a bankfull degradation event were 1.53 times more likely with $95 \%$ certainty the odds would fall within a range 1.03-2.45 $(P=0.05)$. In other words, the later the grazing turnout date, the greater the odds of bankfull width widening. Tests for significant interactions among predictors were nonsignificant and therefore not included in the final model.

Odds of bankfull width degradation were also greater as watershed elevation increased. As watershed elevation increased by $100 \mathrm{~m}$, degradation odds were 1.47 times more likely $(P=0.05)$. Standardized estimates (Fig. 2) provided a measure of attribute significance to the model and revealed the shift from grazing strategy level 3 to level 1 to be the most significant contributor to the overall model followed by AVG ON, watershed elevation, and strategy level shift from 3 to 2 . 
Fire and other hydrologic variables did not contribute to models.

Interpretation of Log Odds Equation and Odds Ratio Estimates. The logits, or log odds of the event occurrence, comprised the predictor coefficients for the binary logistic regression model (eq. 1). Odds ratio estimates were produced through a transformation of logits. For example, the odds ratio of the average grazing start date (AVG ON) corresponded to the 0.078 logit, as $\mathrm{e}^{0.078}$ was approximately -2.55 . The $\log$ odds equation (eq. 1) was transformed to generate a more easily interpretable probability equation (eq. 2) from which the probability of a degradation event was calculated:

$$
\begin{aligned}
\ln [P /(1-P)]= & -9.97-2.55(\text { STRAT } 1 \text { Level } 3: \text { Level } 1) \\
& -0.88(\text { STRAT } 1 \text { Level } 3: \text { Level } 2) \\
& +0.43(\text { AVG ON }) \\
& -0.39(\text { Watershed Elevation })
\end{aligned}
$$

or

$$
\begin{aligned}
\mathrm{P}=1 /\{1 & +\exp [9.97+2.55(\text { STRAT } 1 \text { Level } 3: \text { Level } 1) \\
& +0.88(\text { STRAT } 1 \text { Level } 3: \text { Level } 2) \\
& -0.43(\text { AVG ON }) \\
& +0.39(\text { Watershed Elevation })]\}
\end{aligned}
$$

where

STRAT $13: 1=$ Grazing strategy one comparison of level 3 (continuous use) to level 1 (rest within recent years)

STRAT $13: 2=$ Grazing strategy one comparison of level 3 (continuous use) to level 2 (rotational grazing)

AVG $\mathrm{ON}=$ Average annual grazing start date and

WS Elevation=Elevation of study site watershed.

From the probability equation (eq. 2) probability plots were produced for the four significant contributing predictors to aid in visual interpretation of study-specific predictor-response relationships (Fig. 3). The plots for AVG ON and watershed elevation revealed a positive relationship in which the probability of a degradation event increased as the independent variable increased. Degradation event probability for bankfull width also increased with a shift in grazing strategy from rest or rotation to continuous use.

\section{Results Summary}

In three models produced, grazing measures contributed significantly to two models (Table 3). Geomorphic and hydrologic variables contributed to two models. Fire did not play a significant role for any modeled attribute. The fining of dominant bottom material and bank cover rating decrease could not be modeled with any available predictors. Odds ratio estimate figures, equations, and probability plots are included for all models in Figures S1-S3 (Available online at http://dx. doi.org/10.2111/REM-D-11-00065.s1).

Corresponding model probability equations and fit and predictive accuracy statistics for each model are presented in Table 4. The Hosmer and Lemeshow goodness-of-fit test revealed all models failed to reject the null hypothesis that no

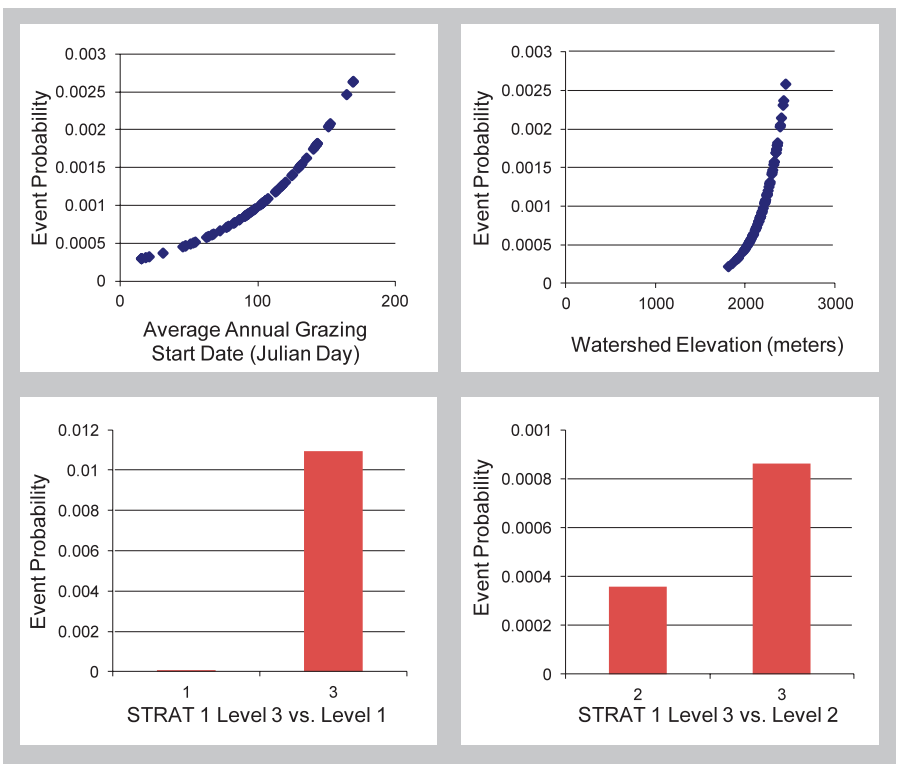

Figure 3. Probability of a bankfull width increase event in relation to significant model predictors. Significant predictor probabilities were calculated for the range of data set observations for the predictor of interest while the other model predictor was held at a constant variablespecific mean value. STRAT 1: grazing strategy one.

differences existed between observed and expected frequencies, thereby suggesting models to be well fitted. In addition, relatively high $R^{2}$ values, high $\mathrm{C}$ statistics, and low Brier scores supported the notion of goodness-of-fit. Predictive accuracy fell within a range $68.4-80 \%$ for all models at a cutpoint of 0.50 .

\section{DISCUSSION}

The detection of no difference in median baseline dominant bottom material rating when compared to median resurvey dominant bottom material rating explained the inability to model this attribute. The detection of a slight, yet nonsignificant, difference in bank cover rating from baseline measurement to resurvey measurement also hindered the modeling ability for bank cover rating.

Grazing attributes contributed to two of the three models. Livestock grazing is the model component for which managers have the greatest capacity to influence degradation odds. For example, problematic riparian livestock grazing can influence bankfull width most directly through mechanical hoof impact, through prolonged, ill timed, or overutilization and weakening of riparian stabilizing species that maintain bank resistance to erosive forces and capture sediment (Clary et al. 1996; Winward 2000; Wyman et al. 2006). Results indicate a shift in grazing strategy one (STRAT 1) from continuous use (Level 3 ) to some rest within recent years (Level 1), average grazing start date (AVG ON), and watershed elevation were the primary drivers of the bankfull width model (Fig. 3).

As a geomorphic indicator of channel function, bankfull width serves as a measurement to track progress related to the management goals and objectives of improved fish habitat, channel stability, and water quality (Swanson et al. 2006). 
Table 3. Units, odds ratio estimates, $95 \%$ confidence intervals, and $P$ values for the predictor variables comprising channel change models.

\begin{tabular}{|c|c|c|c|c|c|c|}
\hline \multirow[b]{2}{*}{ Degradation event modeled } & \multirow[b]{2}{*}{ Model predictors } & \multirow[b]{2}{*}{ Unit } & \multirow[b]{2}{*}{ Odds ratio estimate } & \multicolumn{2}{|c|}{ 95\% confidence interval } & \multirow[b]{2}{*}{$P$ value } \\
\hline & & & & lower & upper & \\
\hline \multirow[t]{4}{*}{ 1. Bankfull width increase } & STRAT 1: Level 3 vs. Level 1 & Change in level & 0.078 & 0.004 & 0.522 & 0.0256 \\
\hline & STRAT 1: Level 3 vs. Level 2 & Change in level & 0.415 & 0.119 & 1.367 & 0.1532 \\
\hline & AVG ON & 30 Julian d & 1.535 & 1.028 & 2.447 & 0.0489 \\
\hline & Watershed elevation & $100 \mathrm{~m}$ & 1.474 & 1.013 & 2.247 & 0.0528 \\
\hline 2. Dominant bottom material fining & Unable to model & & & & & \\
\hline \multirow[t]{2}{*}{ 3. Riparian width decrease } & Precipitation mean & $20 \mathrm{~cm}$ & 10.610 & 2.110 & 76.102 & 0.0098 \\
\hline & Survey year precipitation & $10 \mathrm{~cm}$ & 0.272 & 0.091 & 0.642 & 0.0088 \\
\hline 4. Bank cover rating decrease & Unable to model & & & & & \\
\hline 5. Bank stability rating decrease & AVG GSDG & $25 d$ & 1.629 & 1.078 & 2.525 & 0.0228 \\
\hline
\end{tabular}

Narrowing stream widths, often associated with improved width/depth ratios, more efficiently transport sediment in nonflood periods and provide the overhanging banks and deeper water of great importance to fisheries and water quality (Platts 1991; Prichard et al. 1998). If the management objective is to reduce or prevent an increase in bankfull width, study results suggest implementation of a grazing strategy that favors rest, rotation, and an earlier turnout date.

Provenza (2003) advised grazing strategies that shorten the duration of use and provide growing season rest, deferment, or complete rest and recovery of pastures. This reduces impact with the added benefit of lessening selective grazing of the most palatable species, which are often associated with riparian zones. In addition, spring grazing with an early start date encourages use of highly nutritious upland species, thereby dispersing use throughout a pasture while reducing riparian impacts (Clary and Booth 1993; Bailey 2005) and providing time for streambank vegetation to recover from grazing before winter and energetic spring flows (Wyman et al. 2006).

Watershed elevation played a significant role in the bankfull width model only. The model suggests that as the elevation of the watershed increases, the odds of bankfull width widening are 1.47 times more likely. There are a number of influential factors that could be driving this relationship and warrant further investigation. It is possible that upper watershed streams were relatively more functional during the time of baseline survey and potentially had more to lose over the study duration. Schmidt (2008) in a similar study found higher baseline measurements were always related to a decrease in modeled event and vice versa. He attributed findings to either 1) baseline measurement error corrected by the resurvey measurement or 2) the dynamic nature of steams resulting in "self-adjustment."

Average growing season days grazed (AVG GSDG) was the primary variable driving the bank stability rating decrease model (Table 3; Fig. S3). As the number of days grazed during the growing season increased, the odds of bank stability degradation also increased. This relationship supports the notion of limited grazing during the growing season as a riparian complementary strategy. The evidence for limited growing season use in regard to bank stability is very similar to that previously discussed for bankfull width.

Precipitation mean (average precipitation for the 1970-2000 water years) and the resurvey water year precipitation had inverse effects on riparian width decrease. However, odds ratio estimates revealed precipitation mean had relatively more predictive weight than resurvey year precipitation, suggesting long-term precipitation was a stronger driver of riparian width. As the mean precipitation increased by $20 \mathrm{~cm}$, the odds of a decrease in riparian width increased. We conjecture that 1 ) the model may be reflecting the underlying effects of below average precipitation during the 1999-2003 water years, 2) long-term precipitation had the potential to increase channel width in a confined drainage bottom at the cost of area formerly occupied by riparian vegetation and therefore reduced the established riparian width, or 3) the scale at which the precipitation data

Table 4. Summary table of logistic regression probability equations, number of observations included in model, number of events, number of nonevents, Hosmer and Lemeshow goodness-of-fit statistics, C statistics, Brier scores, and overall predictive accuracy percentages.

\begin{tabular}{|c|c|c|c|c|c|c|c|c|}
\hline Model probability equation & $N$ & Event & Nonevent & $R^{2}$ & $\begin{array}{c}\text { Hosmer } \\
\text { Lemeshow's } \\
\text { goodness-of-fit } \\
\quad(>0.05)\end{array}$ & $\begin{array}{l}\text { Model C } \\
\text { statistic }\end{array}$ & $\begin{array}{l}\text { Model Brier } \\
\text { score }\end{array}$ & $\begin{array}{l}\text { Predictive } \\
\text { accuracy } \\
\text { (cut-point } \\
=0.50 \text { ) }\end{array}$ \\
\hline $\begin{array}{l}\text { 1. Bankfull width increase: } P=1 /\{1+\exp [9.97+2.55 \text { (STRAT } 1 \\
\text { Level } 3: \text { Level } 1)+0.88 \text { (STRAT } 1 \text { Level } 3: \text { Level } 2)-0.43(\text { AVG ON) } \\
-0.39 \text { (Watershed elevation) }]\}\end{array}$ & 72 & 21 & 52 & 0.28 & 0.13 & 0.78 & 0.17 & 70.8 \\
\hline 2. Dominant bottom material fining: unable to model & 80 & 23 & 57 & & & & & \\
\hline $\begin{array}{l}\text { 3. Riparian width decrease: } P=1 /\{1+\exp [-0.21-2.36 \text { (precipitation } \\
\text { mean) }+1.30 \text { (survey year precipitation) }]\}\end{array}$ & 76 & 22 & 54 & 0.19 & 0.12 & 0.71 & 0.18 & 68.4 \\
\hline 4. Bank cover rating decrease: unable to model & 56 & 26 & 30 & & & & & \\
\hline 5. Bank stability rating decrease: $P=1 /\{1+\exp [2.43-0.49$ (AVG GSDG) $]\}$ & 80 & 16 & 64 & 0.10 & 0.36 & 0.68 & 0.15 & 80.0 \\
\hline
\end{tabular}


were collected do not accurately represent the site-specific hydrologic dynamics. Resurvey year precipitation, the least significant model component, produced a counter-relationship in which an increase in survey-year precipitation decreased the odds of riparian width degradation. Though the least significant model component, the resampling water year precipitation relationship is more intuitive. Riparian vegetation responded positively to the resurvey year precipitation increase and possibly associated increase in soil water, thereby reducing the odds of a decrease in riparian width. Further investigation of additional sites is clearly needed to understand the long-and short-term precipitation dynamics driving riparian width changes over time and the potential for incision, extensive bank scouring, or recovery to influence these relationships.

Fire was not a significant contributor to any of the models in this study. Kozlowski et al. (2007) in a related study attributed the low riparian impact of the 1999-2001 northern Nevada fires to the lower severity of riparian fires relative to adjacent uplands and to low postfire precipitation. Fire severity was especially low where only a small fraction of watershed burned and where the site was close to the fire edge. However, it is possible the timing of the resurvey $5 \mathrm{yr}$ postfire may have challenged the detection of fire effects. These interactive relationships warrant further exploration.

Log odds equations when converted to probability equations provided an alternative visual assessment tool for predictorresponse relationships. Graphic representation of probability equations revealed low event probabilities for certain predictors (e.g., bankfull width degradation; Fig. 3) and high for others (e.g., riparian width; Fig. S3). Additionally probability plots may indicate important or widespread threshold values for some variables at which point degradation probability suddenly increases or decreases. Knowledge of probability thresholds could keep managers from misdiagnosing causes or thinking erroneously that they could influence certain degradation events. In general, when streams and riparian areas are farther away from their potential, their response is easier to detect and faster, at least when ready to change after gully widening (Prichard et al. 1998) and an appropriate change in management.

\section{IMPLICATIONS}

Positive changes detected for four out of five stream survey measures revealed that recovery occurred for most modeled attributes over the baseline to resurvey period for 81 northern Nevada streams. Predictor-response relationships identified through binary logistic regression implied recovery of response variables was driven by 1) livestock grazing timing and rotation components and watershed elevation for the bankfull width model, 2) livestock grazing timing for the bank stability model, and 3) hydrologic components for the riparian width model. The occurrence of wildfire during the 1999-2001 fire seasons played a noninfluential role in the response of the selected stream survey attributes when coupled with livestock grazing attributes. Grazing attributes explained variance for the bankfull width and bank stability models that in a previous study (Schmidt 2008) had been attributed solely to natural drivers. A shift to earlier turnout dates, a shift of grazing strategies from continuous use to application of rest and rotation, and a decrease in length of growing season grazed decreased the incidence of bankfull width and bank stability degradation for northern Nevada riparian areas. Livestock grazing is the channel change driver in our study that land managers have the greatest ability to manipulate. Riparian objectives for northern Nevada streams associated with long-term functional recovery may be achieved through implementation of riparian complementary strategies such as earlier season grazing, limited use during the critical growing season, and rest and rotation. We assume that such strategies will be most effective when planned for site-specific applications and modified as monitoring indicates the need for change. When rapid recovery is possible due to dramatic departure from potential and readiness to change (e.g., widened gully and colonizing vegetation; Winward 2000), simple monitoring such as a stream survey (BLM 2002) may be sufficient. As recovery slows because the rapid easy recovery has been achieved, monitoring continued progress may require more detailed measurements and statistical analysis such as enabled by numerous subplots in representative designated monitoring areas (Burton et al. 2011).

\section{ACKNOWLEDGMENTS}

K.N.D. thanks Sherm Swanson, George Fernandez, and Ben Bruce for their guidance and support with study design and analysis. The manuscript was improved with help from Sherman Swanson, Graham Dalldorf, and Ryan Shane. Don Kozlowski, Kurtiss Schmidt, and Ryan Shane provided much of the data utilized in this study. Staff at Northern Nevada Bureau of Land Management and Forest Service offices also provided valuable support.

\section{LITERATURE CITED}

BAllEY, D. W. 2005. Identification and creation of optimum habitat conditions for livestock. Rangeland Ecology \& Management 58:109-118.

[BLM] US Department of the Interior-Bureau of Land Management. 2002. Aquatic Habitat Inventory and Monitoring Level III Survey procedures-transect method. Elko, NV, USA: US Department of the Interior-Bureau of Land Management. Elko Field Office Revised Handbook 6720-1. 47 p.

[BLM]. 2006. Nevada geospatial data. Available at: http://www.blm.gov/nv/st/en/ prog/more_programs/geographic_sciences/gis/geospatial_data.html. Accessed 10 September 2006.

Briske, D. D., J. D. Derner, J. R. Brown, S. D. Fuhlendorf, W. R. Teague, K. M. Havstad, R. L. Gillen, A. J. AsH, AND W. D. WilLms. 2008. Rotational grazing on rangelands: reconciliation of perception and experimental evidence. Rangeland Ecology \& Management 61:3-17.

Brunson, M. W., And B. A. Shindler. 2004. Geographic variation in social acceptability of wildland fuels management in the Western United States. Society and Natural Resources 17:661-678.

Burton, T. A., E. R. Cowley, and S. J. Smith. 2011. Monitoring streambanks and riparian vegetation-multiple indicators. Version 5.0. Boise, ID, USA: US Department of the Interior-Bureau of Land Management Idaho State Office. $57 \mathrm{p}$.

Chambers, J. C. 2008. Fire in the Great Basin. In: J. C. Chambers, N. Devoe, and A. Evenden [EDS.]. Collaborative management and research in the Great Basinexamining the issues and developing a framework for action. Fort Collins, CO, USA: USDA Forest Service Rocky Mountain Research Station. General Technical Report RMRS-GTR-204. p. 33-37.

Clary, W. P., and G. D. Booth. 1993. Early season utilization of mountain meadow riparian pastures. Journal of Rangeland Management 46:493-497. 
Clary, W. P., C. I. Thornton, and S. R. Авт. 1996. Riparian stubble height and recovery of degraded streambanks. Rangelands 18:137-140.

Clary, W. P., and B. F. Webster. 1989. Managing grazing of riparian areas in the Intermountain Region. Ogden, UT, USA: USDA Forest Service Intermountain Research Station. General Technical Report INT-263. 11 p.

Davison, J., AND E. Smith. 1997. Greenstrips: another tool to manage wildfire. Reno, NV, USA: University of Nevada Cooperative Extension. Fact Sheet-97-36. 3 p.

Diamond, J. M. 2009. Effects of targeted grazing and prescribed burned on fire behavior and community dynamics of a cheatgrass (Bromus tectorum)dominated landscape [dissertation]. Logan, UT, USA: Utah State University. $152 \mathrm{p}$.

Dwire, K. A., AND J. B. KaufFman. 2003. Fire and riparian ecosystems in landscapes of the western USA. Forest Ecology and Management 178:61-74.

[ESRI] Environmental Systems Resource Institute. 2009. ArcMap 9.3.1. Redlands, CA, USA: ESRI.

Fernandez, G. 2003. Data mining using SAS applications. Boca Raton, FL, USA: CRC Press. $367 \mathrm{p}$.

Hosmer, D. W., AND S. LemeSHOw. 2000. Applied logistic regression. New York, NY, USA: John Wiley and Sons. $373 \mathrm{p}$.

KozlowskI, D. F. 2007. Pre-fire functional condition and post-fire channel changes in northern Nevada streams: the 1999-2001 fires [thesis]. Reno, NV, USA: University of Nevada, Reno. $176 \mathrm{p}$.

Kozlowski, D., S. Swanson, And K. Schmidt. 2010. Channel changes in burned streams of northern Nevada. Journal of Arid Environments 74:1494-1506.

Launchbaugh, K. B., M. Brammer, L. Brooks, S. Bunting, P. Clark, J. Davison, M. Fleming, R. Kay, M. Pellant, D. A. Pyke, and B. Wylie. 2008. Interactions among livestock grazing, vegetation type, and fire behavior in the Murphy Wildland Fire Complex in Idaho and Nevada, July 2007. Reston, VA, USA: US Geological Survey. Open-File Report 2008-1214.42 p.

Manning, M. E., And W. G. Padgett. 1995. Riparian community type classification for Humboldt and Toiyabe National Forests, Nevada and Eastern California. Ogden, UT, USA: USDA Forest Service Intermountain Region. Report R4-Ecol-95-01. 306 p.

McAdoo, J. K., B. W. Schultz, S. R. Swanson, and G. Black. 2007. Northeastern Nevada wildfires 2006: part 2-can livestock grazing be used to reduce wildfires? Reno, NV, USA: University of Nevada Cooperative Extension. Report FS-07-21. 4 p.

McKenzie, D., Z. Gedalof, D. L. Peterson, and P. Mote. 2004. Climatic change, wildfire, and conservation. Conservation Biology 18:890-902.

MlLleR, R. F., AND R. J. TAUSCH. 2001. The role of fire in pinyon and juniper woodlands: a descriptive analysis. In: K. E. M. Galley and T. P. Wilson [EDS.]. Proceedings of the invasive species workshop: the role of fire in the control and spread of invasive species. Tallahassee, FL, USA: Tall Timbers Research Station. Miscellaneous Publication No. 11. p. 15-30.

MlLLeR, V. C. 1953. A quantitative geomorphic study of drainage basin characteristics in the Clinch Mountain area, Virginia and Tennessee. New York, NY, USA: Department of Geology, Columbia University. Office of Naval Research Technical Report No. 3.

National Climatic Data Center. 2003. Climate of 2003-June, Nevada drought. Available at: http://www.ncdc.noaa.gov/oa/climate/research/2003/jun/ st026dv00pcp200306.html. Accessed 15 December 2008.
Omernick, J. M. 1987. Ecoregions of the conterminous United States (map supplement). Annals of the Association of American Geographers 77:118-125.

Peterman, R. M. 1990. Statistical power analysis can improve fisheries research and management. Canadian Journal of Fisheries and Aquatic Sciences 47:2-15.

PLATTS, W. S. 1991. Livestock grazing. In: W. R. Meehan [ED.]. Influence of forest and rangeland management on salmonid fishes and their habitats. Bethesda, MD, USA: American Fisheries Society. Special Publication No. 19. p. 389-423.

Prichard, D., J. C. Anderson, C. Corell, J. Fogg, K. Gebhardt, R. Krapf, S. Leonard, B. Mitchell, AND J. StaATS. 1998. Riparian area management: a user guide to assessing proper functioning condition and supporting science for lotic areas. Denver, CO, USA: USDI-BLM, USDA-USFS, and USDA-NRCS. Technical Reference 1737-15. $136 \mathrm{p}$.

PRism (Parameter-elevation Regressions on Independent Slopes Model) Group. 2006. Precipitation data. Available at: http://www.ocs.oregonstate.edu/prism/index. phtml. Accessed 20 March 2006.

ProvenzA, F. D. 2003. Foraging behavior: managing to survive in a world of change. Logan UT, USA: Department of Forest, Range and Wildlife Sciences, Utah State University. $64 \mathrm{p}$.

RosGen, D. 1996. Applied river morphology: wildland hydrology. Pagosa Springs, C0, USA: Wildland Hydrology Books. 390 p.

SchmelzeR, L. 2009. Reducing fuel load of key cheatgrass (Bromus tectorum L.) dominated range sites by the use of fall cattle grazing [thesis]. Reno, NV, USA: University of Nevada. $126 \mathrm{p}$.

ScHмid, K. M. 2008. Differences between burned and unburned riparian systems in northern Nevada [thesis]. Reno, NV, USA: University of Nevada. $60 \mathrm{p}$.

Scнmid, K. N. 2009. Riparian response to the interactive effects of livestock grazing and wildfire in Northern Nevada [thesis]. Reno, NV, USA: University of Nevada. $195 \mathrm{p}$.

Svejcar, T., and K. Havstad. 2009. Improving field-based experimental research to compliment contemporary management. Rangelands 31(5):26-30.

Swanson, S., B. Bruce, R. Cleary, B. Dragt, G. Brackley, G. Fults, J. Linebaugh, G. McCuin, V. Metscher, B. Perryman, P. Tueller, D. Weaver, and D. Wilson. 2006. Nevada rangeland monitoring handbook, 2nd ed. Reno, NV, USA: University of Nevada Cooperative Extension and College of Agriculture, Biotechnology, and Natural Resources, USDI-BLM, USDA-USFS, USDA-NRCS, and Nevada Department of Agriculture. Educational Bulletin 06-03. $81 \mathrm{p}$.

Trimble, S. W., And A. C. Mendel. 1995. The cow as a geomorphic agent-a critical review. Geomorphology 13:233-253.

[USFS] USDA Forest SERVICE. 1985. Fisheries habitat survey handbook. Ogden, UT, USA: USFS. USFS Intermountain Region Report 94-FSH 2609-23.

[USGS] US Geological Service. 2006. National elevation data set. Washington, DC, USA: USDI-USGS. Available at: http://ned.usgs.gov. Accessed 1 May 2006.

Winward, A. H. 2000. Monitoring the vegetation resources in riparian areas. Ogden, UT, USA: USDA Forest Service Rocky Mountain Research Station. General Technical Report RMRS-GTR-47. 49 p.

Wyman, S., D. W. Balley, M. Borman, S. Cote, J. Eisner, W. Elmore, B. Leinard, S. Leonard, F. Reed, S. Swanson, L. Van Riper, T. Westfall, R. Wiley, and A. Winward. 2006. Riparian area management-grazing management processes and strategies for riparian-wetland areas. Denver, CO, USA: USDI-BLM, USDA-USFS, and USDA-NRCS. Technical Reference 737-20. 120 p. 